\title{
Geochemistry of heavy metals and sedimentation rate in a bay adjacent to the Caspian Sea
}

\author{
*A. R. Karbassi and R. Amirnezhad \\ Department of Environmental Science, Graduate School of the Environment and Energy, Science and Research Campus, \\ Islamic Azad University, Tehran, Iran
}

\begin{abstract}
In the present investigation down core variations of heavy metals such as; $\mathrm{Zn}, \mathrm{Ni}, \mathrm{Co}, \mathrm{Mn}, \mathrm{Fe}$ and $\mathrm{Al}$ in a sediment core from Bay of Gorgan adjacent to the Caspian Sea was studied. Inter-relationship amongst various parameters was brought out through correlation coefficients and cluster analysis. The results of present study reveals that $\mathrm{Zn}, \mathrm{Ni}, \mathrm{Co}$ and $\mathrm{Mn}$ possess both lithogenous and non-lithogenous sources. The increasing trend of $\mathrm{Al}$ towards top of sediment core is indicative higher erosion in the recent years. Interestingly, concentration of all studied metals increases toward core top (except for Fe) that might be indicative of influence of man's activities residing in catchment area of Gorgan Bay and also oil exploration in the Caspian Sea. Further, ${ }^{210} \mathrm{~Pb}$ and ${ }^{137} \mathrm{Cs}$ techniques were used to find out rate of sedimentation. The result of dating is indicative of sedimentation rate between 1.4 to $2.45 \mathrm{~mm} / \mathrm{yr}$. based on ${ }^{210} \mathrm{~Pb}$ and ${ }^{137} \mathrm{Cs}$ activities respectively.
\end{abstract}

Key words: Heavy metals, ${ }^{210} \mathrm{~Pb},{ }^{137} \mathrm{Cs}$, core, sediment, Gorgan bay, Caspian Sea

*Corresponding Author, E-mail: karbassi@iranenergy.org.ir

\section{Introduction}

Bays comprise a complex system involving interplay between various physical, chemical and biological factors (Hutchinson, 1957; Ruttner, 1963; Mortimer, 1941, 1942 and 1971; Sain and Neufield, 1975 and Coker, et al., 1979). Heat and suspended and dissolved substances are factors that can effect the dispersion of trace elements in the waters, and accumulation or mobilization of trace elements in the sediments of Bays (Al-Masri, 2002 and Butman and Bothner, 1998). Trace metals that are derived from lithogenous and nonlithogenous sources can accumulate in the upper 5 to $20 \mathrm{~cm}$ of Bay sediment. Such accumulation takes place by biological and geochemical mechanisms (Mortimer, 1942 and 1971; Gorham and Swain, 1965; Mackereth, 1966; Cline and Upchurch, 1973; Farmer, 1991 and Rasmussen, 1994). Upward migration of trace metals may occur because of de-watering due to compaction and unidirectional ion migration, but, to a much greater extent, migration appears to be due to bacterial activity (Cline and Upchurch, 1973 and Coker and Shilts, 1979). Most trace metals tend to enrich in the modern organic sediment relative to inorganic sediment (Henderson, 1995 and Kettles, et al., 1991). This is probably due to the nature of the metal-organic binding strength and perhaps increased ion-exchange capacity of organic sediments over inorganic types. Thus, the highest and uniform concentrations of trace metals generally occur in the modern-organic sediment of most Bays (Coker, et al., 1979 and 1995 and Friske, 1995). It is important to identify rates and patterns of sedimentation over the past few centuries. With this information a better prediction of the impact of proposed developments and changes to catchment landuse can result. By analyzing sedimentary records, the chronology of deposition can be determined and changes over time in the characteristics of sediments can be identified. Most of the recent changes are a result of clearing for various purposes, causing increased runoff, discharge, catchment erosion and increased sedimentation in lakes receiving basins. One way to gauge how estuaries have been changing is to have a look at their sedimentary records and use the Lead-210 $\left({ }^{210} \mathrm{~Pb}\right)$ dating method to determine sediment accumulation (Henderson, 1995).In the present investigation, we have tried to establish background or baseline concentration for Zn, $\mathrm{Ni}, \mathrm{Co}, \mathrm{Mn}, \mathrm{Fe}$ and $\mathrm{Al}$ in the Bay of Gorgan 


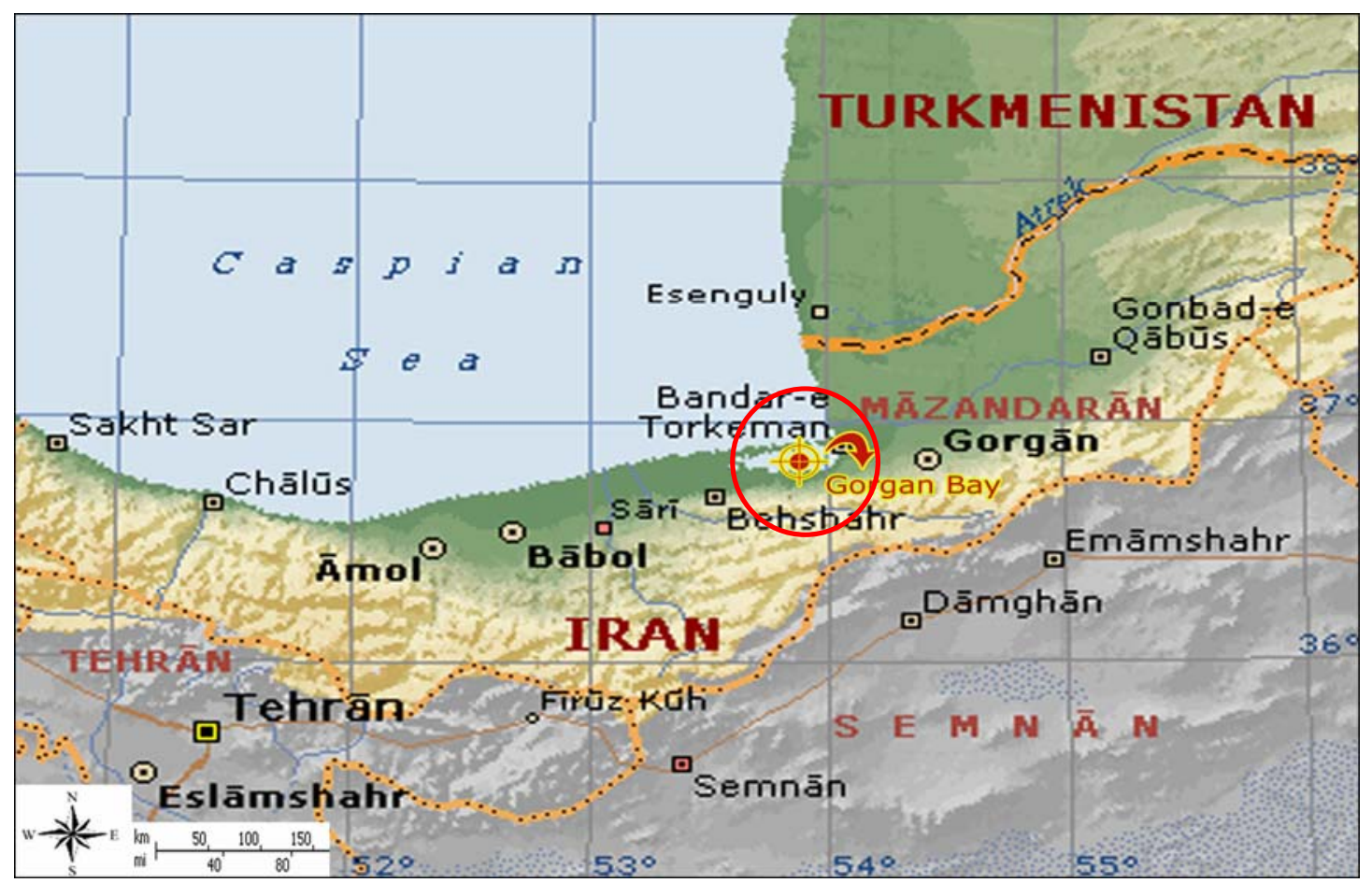

Figure1: Sampeling areas in the central parts of the Bay

and in the other hand to know about sedimentation rate.

\section{Materials and Methods}

The Bay of Gorgan that is located on the southern coasts of Caspian Sea is considered as the largest bay of the Caspian sea. Its area is about $400 \mathrm{Km}^{2}$ with a maximum length of 70 $\mathrm{Km}$. A maximum depth of $5 \mathrm{~m}$ is found in Gorgan Bay (Figure 1). The Qarahsoo river is the only important fresh water source flowing into the Bay.

Using a Pheleger type corer, a sediment sample of $70 \mathrm{~cm}$ length was collected at the central part of the Bay (Lat. 36 $37^{\circ} 45^{\prime \prime}$ Long. $\left.53^{\circ} 05^{\prime} 54^{\prime \prime}\right)$. The core was sliced into identify the increments (top $10 \mathrm{~cm}$ intervals and rest of sediment core at $5 \mathrm{~cm}$ intervals) for geochemical and dating studies. Sediment samples were powdered using agate mortar and pestle. Acids of analytical reagents including $\mathrm{HF}, \mathrm{HNO}_{3}, \mathrm{HCl}$ and $\mathrm{HClO}_{4}$ were used for bulk digestion (Karbassi, 1996). All heavy metal measurement was carried out using aromatic absorption spectrophotimetry model Perkin Elmer at university of Science and Technology in Iran. A variety of approaches have been used to study patterns and processes of bay sedimentation. These include the following methods used to study the geological record of sediment: geophysical surveys (determining
Holocene rates of the past 7,500 years of estuarine sedimentation), bathymetric surveys (comparing $19^{\text {th. }}$ and $20^{\text {th. }}$ century bathymetry), short-lived radioisotopes $\left({ }^{137} \mathrm{Cs},{ }^{210} \mathrm{~Pb}\right)$ and other chemical markers (useful for the past century), and pollen stratigraphy (mainly Ambrosia, ragweed pollen) correlated with land-use changes (documenting postcolonization-land clearance rates).

Monitoring methods not included in the present introduction include instrumental measurement of total suspended solids in water samples and satellite imagery and remote

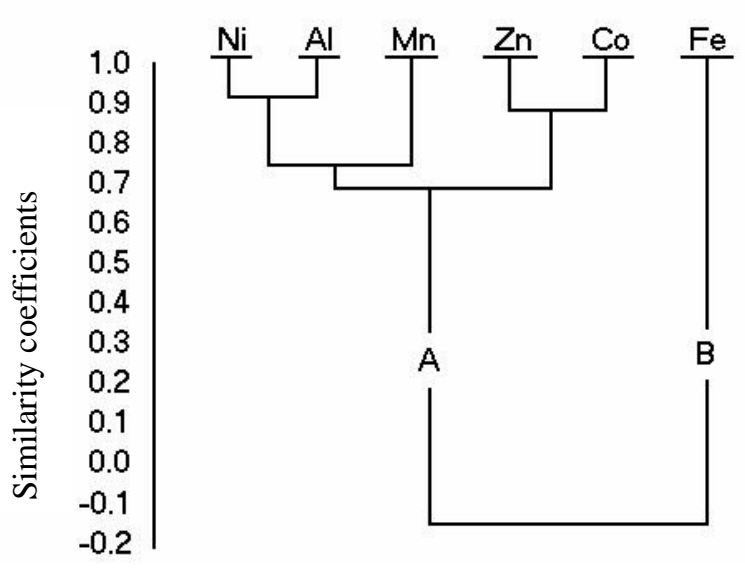

Figure 2: Dendogram of heavy metals in sediment core from Bay of Gorgan 
sensing (Amano and Onuma, 2003 and Jetter, 2000). ${ }^{137}$ Cs activity was counted with a lithium-drifted germanium detector and multi channel analyzer (Huh and Su, 1999). Lead210 (via its granddaughter ${ }^{210} \mathrm{~Pb}$ ) was determined separately in the solution and solid residue resulting from the carbonate analysis. The solutions were separated by settling and decant. The dried residue was transferred to a micro wave digestion bomb, spiked with the same isotopic traces and totally dissolved with micro wave heating of a $\mathrm{HF}^{-} \mathrm{HNO}_{3}$ acid mixture. To eliminate $\mathrm{HF}$ and excess $\mathrm{HNO}_{3}$, the digestion mixture was evaporated with $2 \mathrm{ml}$ $\mathrm{H}_{2} \mathrm{SO}_{4}$. Then the solid residue was re-dissolved in dilute $\mathrm{HNO}_{3}$ and the radionuclides scavanged by precipitating $\mathrm{Fe}$ and $\mathrm{Mn}$, as in foregoing. Polonium isotopes were separated by spontaneous deposition. Excess ${ }^{210} \mathrm{~Pb}$ was calculated as the difference between total ${ }^{210} \mathrm{Po}$ and ${ }^{226}$ Ra decay (Amidi, et al., 1998). Further, it should be noted that lines $662 \mathrm{KeV}$ for Cs and 609 and $1765 \mathrm{KeV}$ for ${ }^{226} \mathrm{Ra}$ were used.

\section{Results}

Concentrations of $\mathrm{Zn}, \mathrm{Ni}, \mathrm{Co}, \mathrm{Mn}, \mathrm{Fe}$ and $\mathrm{Al}$ are presented in Table 1. As seen in the Table, concentrations of all studied metals except for $\mathrm{Fe}$ increase towards top of the sediment core. Many researchers have used sediment cores to study the behavior of metals (Bellucci, et al., 2003; Bertolotto, et al., 2003; Al-Masri, et al., 2002; Borretzen and Salbu, 2002; Weis, et al., 2001; Lee and Cundy, 2001 and Karbassi, 1996 and 1989). A very low concentrations of $\mathrm{Fe}$ and $\mathrm{Al}$ in sediment core when compared with those of mean crust is indicative of low detritus input into the Bay of Gorgan. Concentration of $\mathrm{Zn}$ at the bottom of sediment core is very close to mean crust. However, the highest concentration of $\mathrm{Zn}$ (at the top of sediment core) is almost 1.5 fold higher than mean crust. Figure 2 Shows diagram of cluster analysis amongst studied metals. Cluster "A" consists of five metals namely $\mathrm{Ni}, \mathrm{Al}, \mathrm{Mn}, \mathrm{Zn}$ and $\mathrm{Co}$. It can be seen that origin of $\mathrm{Ni}$ and $\mathrm{Mn}$ is mainly from lithogenous sources taking into account $\mathrm{Al}$ as indicator of detritus matters. However, much of Co concentration could have been derived from anthropogenic origin due to its very high similarity coefficients with $\mathrm{Zn}$. It should be pointed out many researchers use $\mathrm{Zn}$ as oil pollution indicator in the absence of $\mathrm{V}$ (Karbassi, 1989, 1993 and 1996).

As these five elements are clustered together, one may infer that both lithogenous and anthropogenic sources have contributed to the concentrations of studied metals.

Table 1: Concentrations of heavy metals in sediment core from Bay of Gorgan

\begin{tabular}{|cccccccc|}
\hline Depth $(\mathrm{cm})$ & $\mathrm{Zn}$ & $\mathbf{N p m}$ & $\mathrm{Co}$ & $\mathrm{Mn}$ & $\mathrm{Fe}$ & $\mathrm{Al}$ \\
\hline 1 & 95.5 & 35.2 & 15.8 & 516.0 & 0.94 & 0.80 \\
\hline 5 & 97.9 & 34.1 & 14.9 & 487.7 & 1.03 & 0.78 \\
\hline 8 & 88.9 & 32.9 & 12.3 & 483.7 & 1.03 & 0.74 \\
\hline 10 & 86.6 & 30.9 & 13.1 & 488.9 & 1.03 & 0.76 \\
\hline 15 & 88.0 & 32.0 & 12.5 & 502.1 & 1.02 & 0.78 \\
\hline 20 & 90.9 & 36.9 & 13.8 & 568.2 & 1.04 & 0.80 \\
\hline 30 & 78.5 & 36.2 & 11.7 & 441.5 & 1.02 & 0.77 \\
\hline 45 & 81.5 & 33.7 & 12.1 & 489.6 & 1.04 & 0.72 \\
\hline 55 & 76.7 & 24.2 & 11.3 & 428.2 & 1.01 & 0.58 \\
\hline 70 & 67.6 & 24.2 & 10.9 & 413.1 & 1.01 & 0.55 \\
\hline Mean & 85.2 & 32.0 & 12.8 & 482.0 & 1.00 & 0.73 \\
\hline Std (+,-) & 9.20 & 4.50 & 1.60 & 45.00 & 0.03 & 0.08 \\
\hline Mean Crust & 65.0 & 56.0 & 24.0 & 716.0 & 4.32 & 7.96 \\
\hline
\end{tabular}


Iron that forms an individual cluster "B" joins metals of cluster " $A$ " at a very low and negative similarity coefficient. Thus, origin of $\mathrm{Fe}$ needs further investigation by means of chemical partitioning techniques. Activities of ${ }^{210} \mathrm{~Pb}$ and ${ }^{137} \mathrm{Cs}$ are respectively shown in Figures 3 and 4 . According to these activities two different sedimentation rate were obtained. ${ }^{210} \mathrm{~Pb}$ activity is indicative of sedimentation rate of $1.4 \mathrm{~mm} / \mathrm{yr}$.

However, $\quad{ }^{137} \mathrm{Cs}$ activity yields sedimentation rate of $2.45 \mathrm{~mm} / \mathrm{yr}$. As ${ }^{210} \mathrm{~Pb}$ method performs best in relatively quiet depositional environment such as marsh lands (Orson, et al., 1992 and Amano and Onuma, 2003), bays and lakes (Robbins and Edgington, 1975; Ambers, 2001 and Thomson, 2002), we consider it in the further discussion. However, merits of ${ }^{137} \mathrm{Cs}$ is not questioned but such discrepancies often happens at locations where all the ${ }^{137} \mathrm{Cs}$ concentrations are low or near detection limit (Jeter, 2000; Guevara and Arribere, 2002 and Aslani, et al., 2003). If length of sediment core from Gorgan Bay (70 $\mathrm{cm})$ is divided by sedimentation rate (1.4 $\mathrm{mm} / \mathrm{yr}$.), it could be computed that collected core sample is representative of 500 years time span. The variation in concentrations of heavy metals during last 500 years is depicted in Figure 5 (a, b and c).

As shown in Figure 5 (a to $c$ ), the concentrations of all metals except for $\mathrm{Fe}$ decrease towards bottom of sediment core. This is indicative of human influence on the eco-system of Gorgan Bay in the last 500 years. It should be pointed out that increase in the concentration of some trace metals such as $\mathrm{Zn}$ is mainly due to oil activities in the Caspian Sea. However, an increase in the concentration of $\mathrm{Al}$ might be attributed to higher erosion in the area of study that is mainly due to more agricultural activities and improper catchment's management. Based on the present investigation base-line values for metals is proposed in the discussion and conclusions section of this paper. However, for more accurate baseline data, chemical-partitioning technique is suggested. By this technique, association of metals with various sedimentary phases would be known (Karbassi, 1993 and Karbassi and Shankar, 1993). Thus, a more reliable data can be provided for further investigations.

\section{Discussion and Conclusion}

Data to determine trends is commonly gathered by long-term programs that monitor environmental media such as air, water, fish and surface sediments. Theses monitoring programs can continue for years or even decades.

Although aluable, this long-term monitoring can suffer from several shortcomings. These are:

- Such programs can not evaluate conditions prior to the time they were initiated.

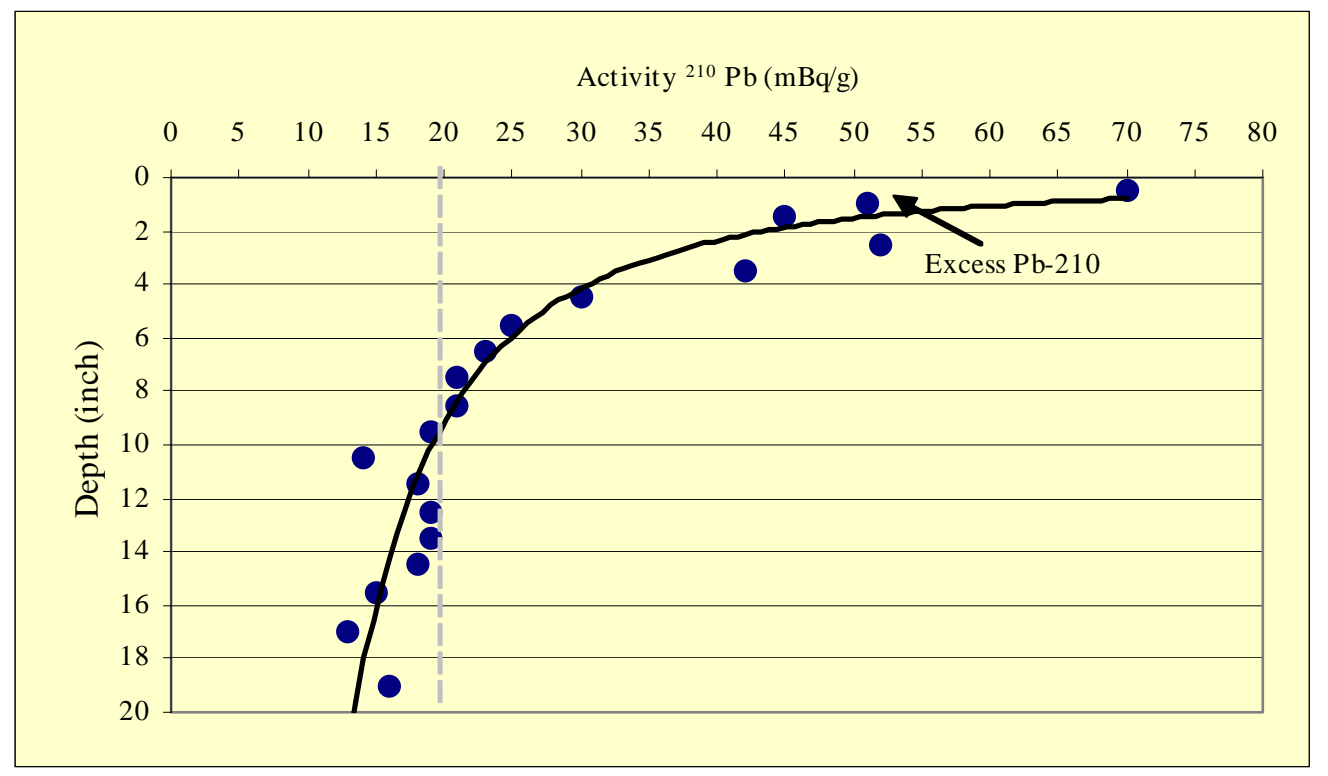

Figure 3: Activity of ${ }^{210} \mathrm{~Pb}$ 


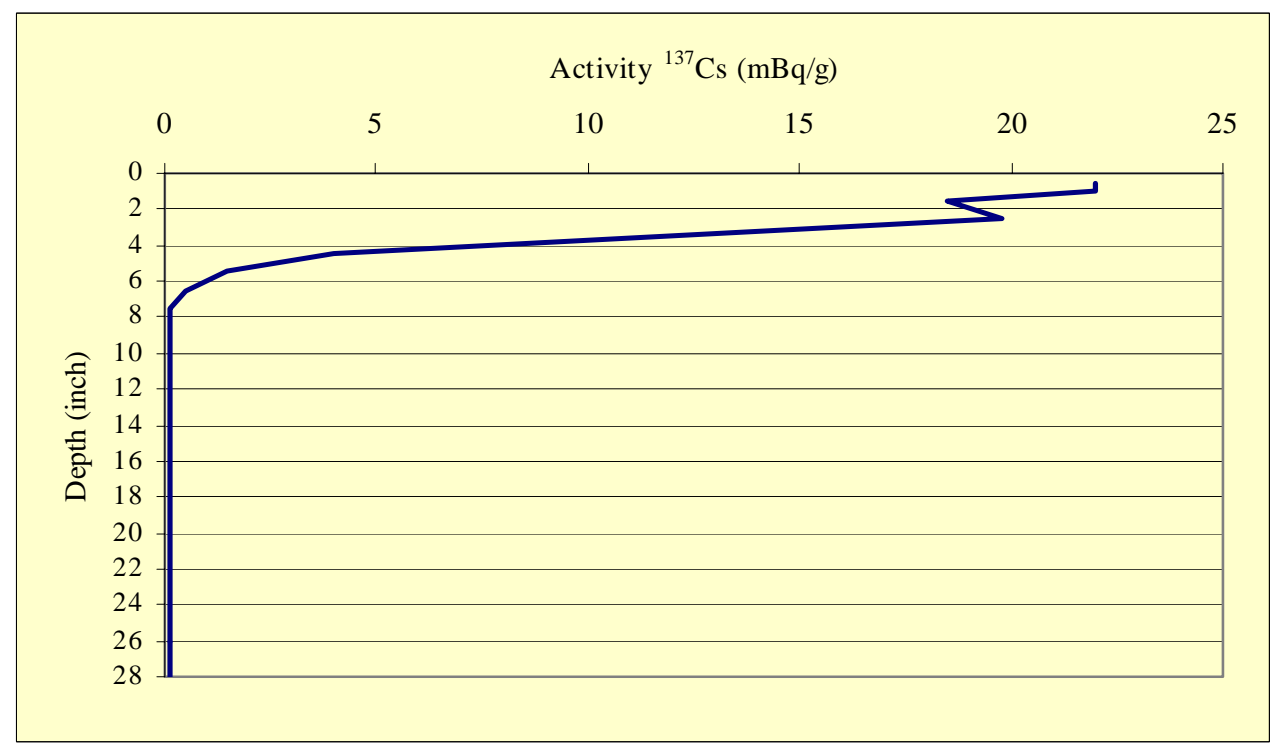

Figure 4: Activity of ${ }^{137} \mathrm{Cs}$

- Changes in sampling and analytical methods can void or compromise comparison with earlier data.

In some cases, analyses of sediment cores can be used to overcome these shortcomings. Concentrations of persistent pollutants (especially metals, radionuclides and refractory organic compounds) can be measured in successive layers within cores. Dating techniques including use of radioactive isotopes like ${ }^{210} \mathrm{~Pb}$ and ${ }^{137} \mathrm{Cs}$ can be used to estimate the age of these layers.By combining concentration data, extended records of pollutant concentrations in sediments can be reconstructed. The eco-system of Bay of
Gorgan is influenced both by water intrusion from the Caspian Sea and to a lesser extent by fresh river waters. Both oil and agricultural activities have left considerable impacts on the eco-system of Bay of Gorgan. If $\mathrm{Zn}$ is considered as an indicator of oil pollution then it can be inferred that oil activities in the Caspian Sea might have contributed to the concentration of $\mathrm{Zn}$. In spite of the fact that concentrations of $\mathrm{Ni}$, Co and $\mathrm{Mn}$ stands well below those of mean crust but as a general role the concentrations of these metals increases towards top of sediment core. Such increase in the concentration of metals may be indicative of human influence on aquatic environment of Bay of Gorgan.

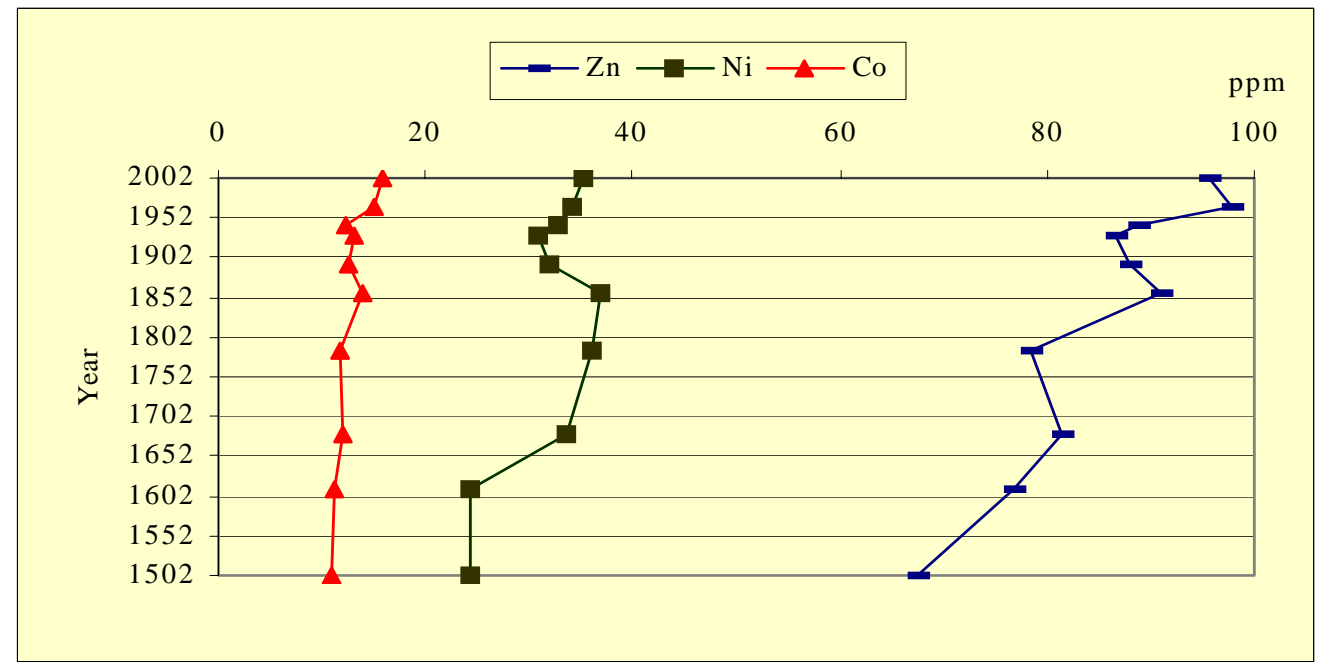

Figure 5 (a): Down core variations of $\mathrm{Zn}, \mathrm{Ni}$ and Co concentrations through span of time 


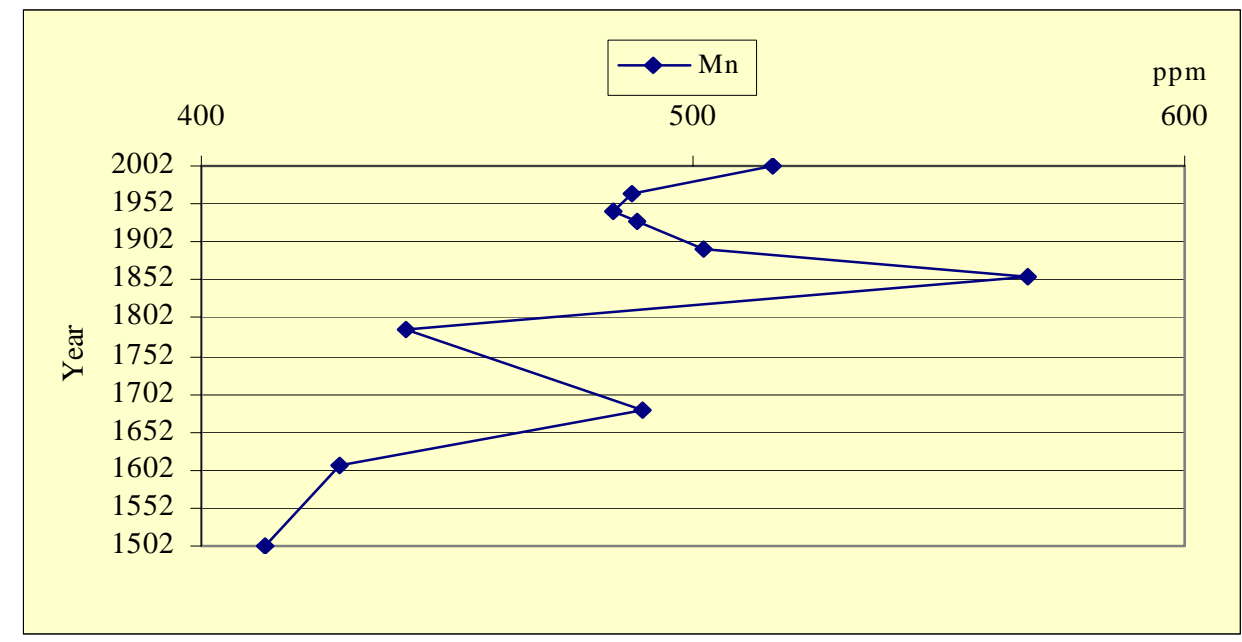

Figure 5 (b): Down core variations of Mn concentrations through span of time

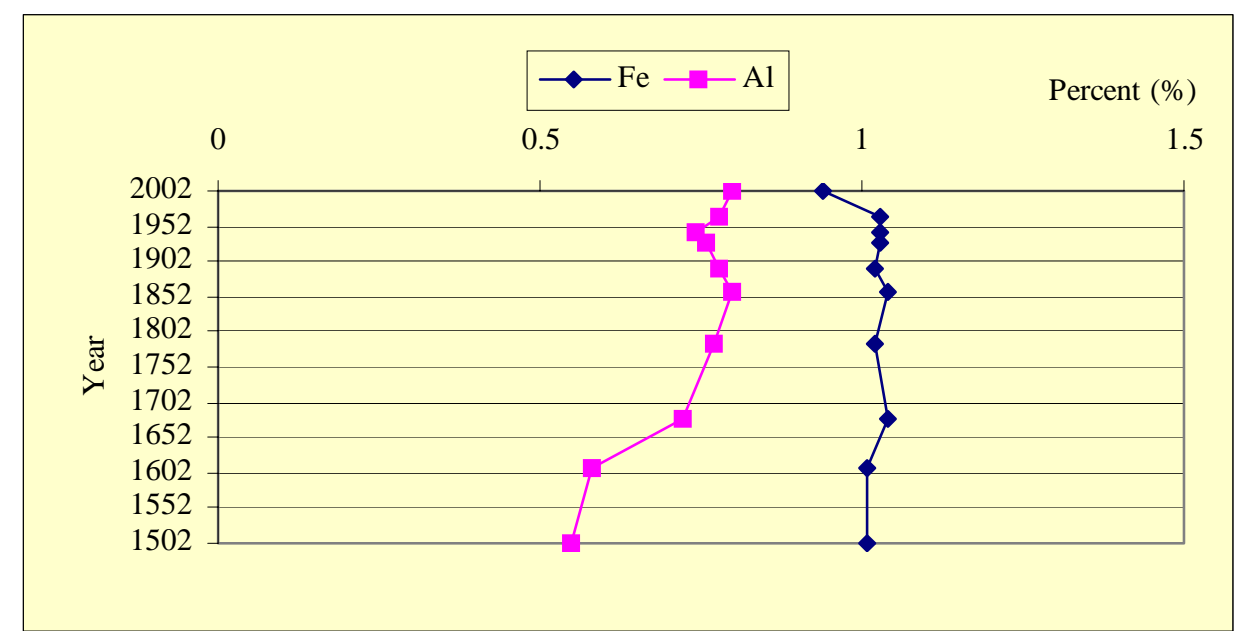

Figure 5 (c): Down core variations of $\mathrm{Fe}$ and $\mathrm{Al}$ concentrations through span of time

Many parts of Caspian Sea have undergone anoxic conditions for discharge of municipal as well as industrial discharges. Under anoxic conditions, Mn can be mobilized and finds its way into the overlying waters. As a great part of Gorgan Bay's water is supplied by the Caspian Sea, it could be inferred that higher concentrations of $\mathrm{Mn}$ at the top of sediment core has been derived from its mobilization in the Caspian Sea. It is proposed the following concentrations as baseline or background values for further investigators whom wish to follow trends of pollution in future. These values correspond to data obtained for metals at 500 years ago. The baseline values are $\mathrm{Zn}=68 \mathrm{ppm}, \mathrm{Ni}=24 \mathrm{ppm}, \mathrm{Co}=11 \mathrm{ppm}$, $\mathrm{Mn}=413 \mathrm{ppm}, \mathrm{Fe}=1 \%$ and $\mathrm{Al}=0.55 \%$. It is much safer to use ${ }^{210} \mathrm{~Pb}$ technique for dating of sediment in Bays. More attention must be paid to themanagement of catchment area tos minimize soil erosion. Further studies must consider chemical-partitioning techniques. Also longer sediment cores must be obtained from Bay of Gorgan for detailed climatological studies through pollen analysis.

\section{Acknowledgements}

Authors wish to appreciate Marine Wing (Department of the Environment) for financial assistance to carry out ${ }^{210} \mathrm{~Pb}$ and ${ }^{137} \mathrm{Cs}$. Dr. Beitollahi from Iran Atomic Energy Organization helped us a lot for sediment core dating. Dr. M. Saeedi from University of Science and Industry kindly helped us to carry our geochemical analysis. Thanks to Dr. I. Bayat and Dr. S. M. T. Sadatipour from Department of Marine Science for their fruitful discussions on dating aspects. 


\section{References}

Al-Masri, M. S., A. Aba, H. Khalil, and Z. Al-Hares, Sedimentation rates and pollution history of a dried lake: Al-Oteibeh Lake. Science of the Total Environment, 293 (1-3):177-189, 2002

Amidi, J., M. M. Beithollahi, and M. Asefi, Calibration of gamma spectrometer with high pure germanium detector. IRNA-NRPD Technical Report, 1998

Amano, H. and Y. Onuma, Depth profiles of long lived radionuclides in Chernobyl soils sampled around 10 years after the accident. Journal of Radio analytical and Nuclear Chemistry, 255 (1): 217-222, 2003

Ambers, R. K. R., Using the sediment record in a western Oregon flood-control reservoir to assess the influence of storm history and logging on sediment yield. Journal of Hydrology, 244 (3-4): 181-200, 2001

Aslani, M .A. A., S. Aytas, S. Akyil, G. Yaprak, G. Yener, and $M$. Eral, Activity concentration of cesium-137 in agricultural soils. Journal of Environmental Radioactivity, 65 (2): 131-145, 2003

Bellucci, L. G., B. El Moumni, F. Collavini, M. Frignani, and S. Albertazzi, Heavy metals in Morocco Lagoon and river sediments. Journal de Physique, IV 107 (Pt. 1): 139-142, 2003

Bertolotto, R. M., B. Tortarolo, M. Frignani, L. G. Bellucci, S. Albanese, and C. Cuneo, Heavy metals in coastal sediments of the Ligurian sea off Vado Ligure. Journal de Physique, IV 107 (Pt. 1): 159162, 2003

Borretzen, P. and B. Salbu, Fixation of Cs to marine sediments estimated by a stochastic modeling approach. Journal of Environmental Radioactivity, 61 (1):1-20, 2002

Butman, B. and Bothner, M. H., Predicting the LongTerm Fate of Sediments and Contaminants in Massachusetts Bay. U.S. Geological Survey Fact Sheet, 172-97, 1998

Coker, W. B. and Shilts, W. W., Lacustrine geochemistry around the north shore of Lake Superior: Implications for the evaluation of the effects of acid precipitation: In Current Research, Part C, Geological Survey of Canada, Paper 791C: 1-15, 1979

Coker, W. B., Hornbrook, E. H. W. and Cameron, E. M., Lake sediment geochemistry applied to mineral exploration: In Geophysics and Geochemistry in the search for Metallic Ores; Peter J. Hood, editor; Geological Survey of Canada, Economic Geology Report 31: 435-478 1979

Coker, W. B., Kettles, I. M. and Shilts, W. W., Comparison of mercury concentrations in modern lake sediments and glacial drift in the Canadian Shield in the region of Ottawa/Kingston to Georgian Bay, Ontario, Canada: Water, Air and Soil Pollution, 80: 1025-1029, 1995

Farmer, J. G., The perturbation of historical pollution records in aquatic systems: Environmental Geochemistry and Health, 13 (2): 76-83, 1991

Cline, J. T. and Upchurch, S. B., Mode of heavy metal migration in the upper strata of lake sediment: In Proceedings of the 16th Conference on Great Lakes Research. International Association on Great Lakes Research, 1: 349-356, 1973

Friske, P. W. B., Effects of limnological variation on element distribution in lake sediments from Tatin lake, central British Columbia - implications for the use of lake sediment data in exploration and environmental studies: In Current Research 1995E, Geological survey of Canada, 4: 59-67, 1995

Gorham, E. and Swaine, D., The influence of oxidizing and reducing conditions upon the distribution of some elements in lake sediments: Limnology and Oceanography, 10: 268-279, 1965

Guevara, S. R. and M. Arribere, Cs-137 dating of lake cores from the Nahuel Huapi National Park, Patagonia, Argentina: Historical records and profiles measurements. Journal of Radioanalytical and Nuclear Chemistry 252 (1): 37-45, 2002

Henderson, P. J., The geochemistry of Lake Winnipeg long cores and bottom sediment samples: Namao cruise 94-900: Geological Survey of Canada, Open File Report 5: 3113, 1995

Huh, C. and Su, C., Sedimentation dynamics in the east China sea elucidated from $\mathrm{Pb}-210, \mathrm{Cs}-137$ and Pu-239-240. Marine Geology, 160: 183-196, 1999

Hutchinson, G. E., A Treatise on Limnology; Volume 1, Geography, Physics and Chemistry: Wiley and Sons, New York, 1015, 1957

Jetter, H. W., Determining the ages of recent sediments using measurements of trace radioactivity. Terra et Aqua, 78: 21-28, 2000 
Karbassi, A. R., Geochemical and magnetic studies of riverine, estuarine and marine sediments. Ph.D. thesis, Mangalore University, India, 196, 1989

Karbassi, A .R., Geochemistry of a sediment core and applications of analysis in interpretating data. The 16 th International Geochemical Exploration Symposium, Beijing, China, 1993

Karbassi, A. R. Geochemistry of Ni, Zn, Cu, Pb, Co, $\mathrm{Cd}, \mathrm{V}, \mathrm{Mn}, \mathrm{Fe}, \mathrm{Al}$ and $\mathrm{Ca}$ in sediments of North Western part of the Persian Gulf. Intl. J. Env. Studies, 54: 205-212, 1996

Karbassi, A. R., and Shankar, R., Geochemistry of two sediment cores from west coasts of India. IAWQ Sediment Conference, Milwaukee, U.S.A, 1993

Kettles, I. M., Shilts, W. W. and Coker, W. B., Surficial geochemistry south-central Canadian Shield: Implications for environmental assessment: In Geochemical Exploration 1989, Part II (A. W. Rose and P.M. Taufen, Editors), Journal of Geochemical Exploration, 41 (1/2): 29-57, 1991

Lee, S. V. and A. B. Cundy, Heavy metal contamination and mixing processes in sediments from the Humber Estuary, Eastern England. Estuarine Coastal and Shelf Science, 53 (5): 619636, 2001

Mackereth, F.J.H., Chemical investigation of lake sediments and their interpretation: Proceedings of the Royal Society, 161: 285-309, 1965

Mortimer, C. H., The exchange of dissolved substances between mud and water in lakes. Part III and IV: Journal of Ecology, 30: 147-207, 1942
Mortimer, C. H., Chemical exchanges between sediments and water in the Great Lakes speculations on probable regulatory mechanisms: Limnology and Oceanography, 16 (2): 387-404, 1971

Orson, R. A., Simpson, R. L., Good, R. E., A mechanism for the accumulation and retention of heavy metals in tidal freshwater marshes of the upper Delaware River estuary. Estuarine Coastal and Shelf Science, 34: 171-186, 1992

Rasmussen, P. E., Current methods of estimating mercury fluxes in remote areas: Environmental Science and Technology, 28 (13): 2233-2241, 1994

Robbins, J. A. and Edgington, D. N., Determination of recent sedimentation rates in Lake Michigan using Pb-210 and Cs-137. Geochim Cosmochim Acta, 39: 285-304, 1975

Ruttner, F., Fundamentals of Limnology: University of Toronto Press, Toronto, 295, 1963

Sain, K.S. and Neufeld, R.D., A dynamic model of biogeochemical cycle of heavy and trace metals in natural aquatic systems: Paper presented at the Second International Symposium on Environmental Biogeochemistry, Burlington, Ontario, Canada, 20, 1975

Thomson, J., F.M. Dyer, and I.W. Croudace, Records of radionuclides deposition in two salt marshes in the United Kingdom with contrasting redox and accumulation conditions. Geochimica et Cosmochimica Acta 66 (6):1011-1023, 2002

Weis, D.A., J.C. Callaway, and R.M. Gersberg, Vertical accretion rates and heavy metal chronologies in wetland sediments of the Tijuana Estuary. Estuaries 24 (6A): 840-850, 2001 